Int. J. Electrochem. Sci., 16 (2021) Article ID: 210814

International Journal of

ELECTROCHEMICAL

SCIENCE

www.electrochemsci.org

\title{
Investigation of Chloride Diffusion Behavior of Concrete Manufactured with Blended Mineral Admixtures Using Electrochemical Technique
}

\author{
Yong-quan Xiong
}

School of Architectural Engineering, Sichuan University of Arts and Science, Dazhou, Sichuan

Province, 635000, China

E-mail: xyq20110026@sina.com

doi: $10.20964 / 2021.08 .03$

Received: 9 April 2021 / Accepted: 18 May 2021 / Published: 30 June 2021

Chloride-induced reinforcement corrosion has already been identified as a significant durability issue in reinforced concrete systems in the world. Here, the chloride ion diffusion in concrete structures blended with furnace slag (FS) and bottom ash (BA) admixtures were studied by soaking and electrochemical impedance spectroscopy (EIS) techniques. According to the EIS findings, increasing the volume of FS and BA improves resistance to chloride ion migration. The use of BA at $30 \%$ helped to increase the compressive strength of the concrete after 28 days of curing time. The soaking results revealed that the F-30BA sample significantly effect on the migration of chloride ions in concrete structures containing FS and BA additives. The surface morphology of steel rebar exhibited that a little corrosion product and slight pits were found on the surface of steel in F-30BA sample which was in the accordance with the results obtained from soaking and EIS tests.

Keywords: Chloride ion diffusion; Mineral admixtures; Reinforced concret; Electrochemical impedance spectroscopy

\section{$\underline{\text { FULL TEXT }}$}

(C) 2021 The Authors. Published by ESG (www.electrochemsci.org). This article is an open access article distributed under the terms and conditions of the Creative Commons Attribution license (http://creativecommons.org/licenses/by/4.0/). 